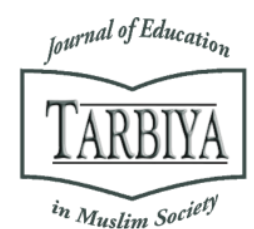

Available online at TARBIYA: Journal of Education in Muslim Society Website:

http://journal.uinjkt.ac.id/index.php/tarbiya

TARBIYA: Journal of Education in Muslim Society, 3(1), 2016, 121-130

\title{
THE ASSESSMENT OF STUDENT PERFORMANCE IN THE PRACTICUM ACTIVITY OF BASIC PHYSICS COURSE
}

\author{
Yuberti $^{1}$, Diana Nomida ${ }^{2}$, Tuti Nuriah ${ }^{3}$ \\ ${ }^{1}$ State Islamic Institute (IAIN) of Lampung, Indonesia \\ ${ }^{2,3}$ State University of Jakarta, Indonesia \\ E-mail: yuberti_iain@yahoo.co.id
}

Received: $27^{\text {th }}$ March 2016; Revised: $15^{\text {th }}$ April 2016; Accepted: $23^{\text {th }}$ May 2016

\section{Abstract}

This study was aimed at obtaining factual information on 1) the assessment of Basic Physics course learning achievement of Physics Education students of the Tarbiyah and Teacher Training Faculty of IAIN Raden Intan Lampung that includes process and product assessment and 2) the results of the implementation of assessment on student performance during the practicum component of the course. The study employed Elliot's Model of Action Research Study, which is a mixed method in nature. It focused on improving instructional condition as the responsibility of the respective lecturer to make it more responsive to the existing needs. Indeed, it requires commitment of all parties involved in the instructional process to participate and collaborate for improved learning achievement, particularly of the Basic Physics course, to be obtained. In conclusion, based on the process and findings of the action research study, the implementation of performance assessment has significantly improved student learning achievement in the Basic Physics course.

Keywords: assessment, performance, achievement

\section{Abstrak}

Penelitian ini bertujuan untuk mendpatkan informasi faktual mengenai 1) penilaian hasil belajar Fisika Dasar Pendidikan Fisika Fakultas Tarbiyah dan Keguruan IAIN Raden Intan Lampung yang meliputi penilaian proses dan kinerja, dan 2) hasil implementasi penilaian prestasi mahasiswa selama praktikum. Penelitian menggunakan Penelitian Tindakan Kelas Model Elliot, yang merupakan metode campuran. Penelitian fokus kepada peningkatan kondisi pembelajaran sebagai tanggungjawab dosen yang bersangkutan untuk membuatnya lebih responsif dengan kebutuhan yang ada. Tentunya, hal ini membutuhkan komitmen dari seluruh pihak terkait dalam proses pembelajaran untuk berpartisipasi dan berkolaborasi untuk peningkatan hasil pembelajaran, khususnya mata kuliah Fisika Dasar. Dapat disimpulkan, berdasarkan proses dan temuan penelitian tindakan kelas, penerapan penilaian kinerja secara signifikan meningkatkan prestasi belajar mahasiswa pada mata kuliah Fisika Dasar.

Kata kunci: penilaian, kinerja, prestasi

How to Cite: Yuberti, Nomida, D., Nuriah, T. (2016). The Assessment of Student Performance in the Practicum Activity of Basic Physics Course. TARBIYA: Journal Of Education In Muslim Society, 3(1), 121-130 doi:10.15408/tjems.v3i1.3397.

Permalink/DOI: http://dx.doi.org/10.15408/tjems.v2i1.3397 


\section{Introduction}

State Islamic Institute Raden Intan Lampung is one of the religious-based university consisting of four faculties, one of which is the Faculty of Education and Teaching. Distribution of subjects presented at the Faculty of Education and Teacher Training courses include Theory and Practice moreover science courses such as Physics Education Study Program. In practical courses that are practiced as subjects Physics, has long carried out, only in practice, most professors do not use assessment instruments that should be done.

Performing practicum in the laboratory is an indispensable activity of the Basic Physics course. To get an objective assessment result of it, all aspects of student achievement should be taken into account. Performance Assessment (PA), a kind of authentic assessment, is a good alternative of assessment to utilize in the practicum program of the course.

With the use of PA, student achievement can be measured along the learning process without having to wait until the end of the lesson. It is supported by Zainul (2001: 10) stating that PA allows the improvement of learning process as it helps teacher make decisions during the lesson. Further, PA emphasizes on the students involvement showing their interim understanding and the reality as Burke (2009: 8) asserts: "Performance Assessments are highly engaging for students because they connect their content knowledge with the processes they will use in the real world". It is in line with the statement of Muchtar (2010: 73) that performance-based assessment is a hands-on assessment measuring a certain actual performance in which students are assigned to carry out valuable and authentic tasks in the real world or authentic contexts. Authentic assessment is also called realistic assessment which is generally associated with the implementation in the real life. Campbell (2006: 67) states that if we use the physicsrelated real occurences for the practical applications, the basics of physics are becoming more relevant and meaningful.

One of the objectives of conducting an assessment is to find out the learning process effectiveness and students' achievement. For this purpose, the assessment tool should be able to disclose the entire student learning achievement. By using PA, students' true responses become observable as suggested by Linn \& Baker:

Performance assessment as a formal assessment method in which a student's skill in carrying out an activity and producing a product is observed and judged (e.g., contruction of a woodworking project; completion of an essay in English, research report in history or laboratory in science.(Reynolds et.al., 2009: 245-246)

PA requires students to show up their competences instead of merely choosing simple answer of several available options. Danilelson (2000: 24) says: "Performance assessment means any assessment of student learning that requires the evaluation of student writing, product, or behavior. That is, it includes all assessment with the exception of multiple choice, matching, true or false testing, or problem with a single correct answer".

In addition, the strengths of PA include its ability to reveal students' potencies in solving problems, reasoning, and communicating orally or in written form. To apply PA, there must be observable and real assignment done by students. They are required to perform their understanding and competencies as the actualization of their knowledge and skills. In other words, they are expected to perform authentic responses in the form of observable activities (Reynolds et.al., 2009: 248).

Performing an assignment is quite complex involving, at least, two observable aspects: 1) 
Procedure, skills or technical matters, and 2) Product or output. If the assessment is on the procedure, it means that the examiner is determining how skillful the examinee is in performing the expected procedure; whereas if the product is being assessed, it highlights the quality of the end result only. Stiggins (2007: 186) asserts: "Performance assessment is complex. It requires users to prepare and conduct their assessment in a thoughtful and rigorous manner. Those unwilling to invest the necessary time and energy will place their student directly in herm's way".

Performance of practicum in the laboratory is a complex process of activity involving plenty of elements, among others, understanding of the nature of practicum itself, utilization of materials and equipment, observation skill, and active participation as Gardner (2003: 274) suggests that students should be able to explain objects and phenomena found in the real life, aside from the the objects exposed in the physics laboratory. Thus, it is urgent for lecturer of science, particularly Basic Physics subject, to conduct PA in order to recognize the students' achievement of the learning objectives indicated by their specific behaviors throughout the activity.

This kind of assessment is believed to be more accountable than using written test since it is dealing with the activity where the students are expected to perform a certain assignment given by the lecturer in the laboratory. Using PA, the lecturer can accurately decide whether or not the students are able to perform the given task appropriately. It can reflect the true competency of students in performing the task of practicum in the laboratory.

This kind of research, focusing on analyzing the implementation of PA, is rarely done in Indonesia. Mostly, research carried out was more emphasized on more general perspectives of assessment, instead of on the practical matters.
As such, the standardized instrument, even the very general one, to measure students' achievement in performing task of practicum in the laboratory does not exist yet.

Relating to the practical use of PA, Faculty of Tarbiyah and Teacher Training as an institution which produces teachers ideally has already applied performance-based assessment to measure students' conceptual understanding actualized in the experimental activities. By referring to the characteristics of the learning objectives of the Basic Physics course, in terms of the basic competencies, expected skills and achievement, it is obvious that the assessment system should be able to reveal all those necessary aspects.

The understanding of process skill by implementing PA is very limited. It may happen due to the misconception occuring among them. It is believed that having good mastery of concepts of physics only is sufficient without having to acquire the mastery of process skill which demands the use of PA. Also, students are not demanded because there are no questions related to the process skill in national exam.

Based on the observation at the Science Major of Tarbiyah and Teacher Training Faculty, it was found out that the process of assessment carried out only aimed at measuring conceptual understanding through objective and subjective tests, the instructional activity was generally focused on explaining the learning materials and excessively exploiting the textbooks/modules. As a result, students tended to only memorize the lesson for the exam. As Basic Physics is a course with practicum activity, the learning output is the combination of process and product assessment. Nevertheless, during the practicum activity, process assessment was never carried out. It was because of the inexistence of manual of PA implementation. This is in line with the statement of Baedhowi (2006: 63) that 
it is not easy to apply assessment tapping the three domains of learning: cognitive, affective and psychomotor due to such factors as (1) low commitment, (2) inadequate knowledge and competence, (3) lack of facilities, (4) unavailability of political will of government and campus management, and (5) ineffective information dissemination.

Result of interview with four lecturers of courses with practicum activity showed that the practicum activity was carried out 8 up to 12 times per semester, yet, PA to measure the process aspect of the activity was not executed. Furthermore, based on the result of interview and observation, it was found out that there was an inconsistency between the learning objectives and the techniques of assessment. Consequently, students' learning achievement was inaccurately measured.

In addition to interview and observation result, the document of Basic Physics student score obviously indicated that process assessment in the form of PA of students in carrying out practicum was not carried out. Student final score was the accumulation of score of attendance, assignment, mid-test, final test and practicum. The score of practicum was the average score of several practicum scores taken by analyzing students report submitted a week after the practicum activity. It means that the practicum score did not definitely reflect their true competence in carrying out the practicum activity.
This condition shows clearly that there is a gap between the learning objective and the technique of assessment. The technique of assessment employed by the lecturer could only figure out student mastery of conceptual understanding. Therefore, a better assessment technique which can disclose the whole aspects of student competencies including process and product is highly needed, in this case by using PA.

This research was intended to describe and analyze: 1). The improvement of student performance score per cycle, 2). The hindrances faced by lecturers in applying PA.

\section{Method}

This research belongs to Action Research (AR) with model of Elliot and using mixed method data analysis. It was used by considering that the data gathered consisted of two different kinds of data, qualitative and quantitative, with the strategy of sequential exploratory design.

According to Cresswell (2003: 213), the strategy can be described by Figure 1 .

Sources of data included students and lecturers of Physics Education Study Program. Data sources, kinds and collecting techniques are displayed in the following Table 1.

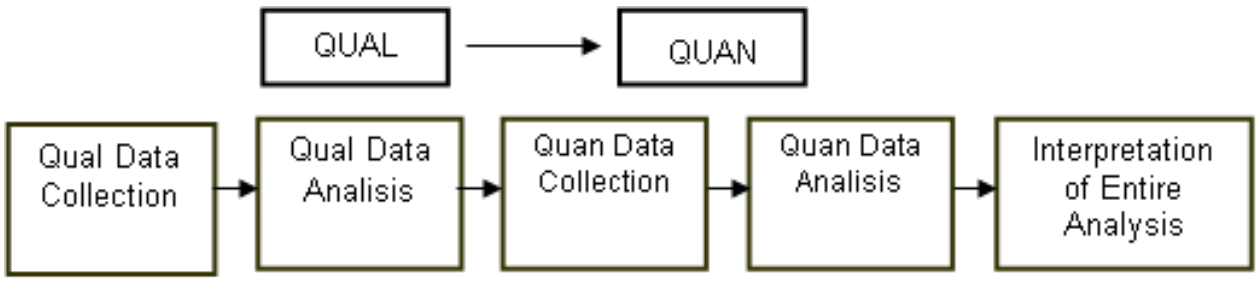

Figure 1. Strategy of Sequential Exploratory Design 
Table 1. Data sources, kinds and collecting techniques

\begin{tabular}{|c|c|c|c|c|}
\hline No. & $\begin{array}{c}\text { Source of } \\
\text { Data }\end{array}$ & Kinds of data & Data Collecting Techniques & Remarks \\
\hline 1 & Lecturers & $\begin{array}{c}\text { Responses upon the use of } \\
\text { PA }\end{array}$ & - interview & $\begin{array}{l}\text { - interview } \\
\text { guidelines }\end{array}$ \\
\hline 2 & Students & $\begin{array}{l}\text { Activities during the } \\
\text { implementation of PA }\end{array}$ & $\begin{array}{l}\text { - observation } \\
\text { - field notes }\end{array}$ & - observation sheet \\
\hline 3 & Students & $\begin{array}{c}\text { Responses upon the use of } \\
\text { PA }\end{array}$ & $\begin{array}{l}\text { - questionnaire } \\
\text { - field notes }\end{array}$ & $\begin{array}{l}\text { - questionnaire } \\
\text { guidelines }\end{array}$ \\
\hline
\end{tabular}

Table 2. Blue Print of Observation Sheet

\begin{tabular}{|c|c|c|c|c|c|c|}
\hline \multirow{2}{*}{ No. } & \multirow{2}{*}{ Aspect } & \multirow{2}{*}{ Sub-Aspect } & \multirow{2}{*}{$\begin{array}{l}\text { Number } \\
\text { of items }\end{array}$} & \multirow{2}{*}{ Item } & \multicolumn{2}{|l|}{ Score } \\
\hline & & & & & 321 & 1 \\
\hline \multirow{6}{*}{1} & \multirow{6}{*}{$\begin{array}{l}\text { Preparation } \\
\text { (1) }\end{array}$} & Recognizing the tools and materials used & $\overline{1}$ & $1 \mathrm{a}$ & & \\
\hline & & $\begin{array}{l}\text { The tools and materials matched with the objective of } \\
\text { experiment }\end{array}$ & 1 & $1 b$ & & \\
\hline & & The accuracy of tool selection & 1 & $1 \mathrm{c}$ & & \\
\hline & & The accuracy of tool usage & 1 & $1 \mathrm{~d}$ & & \\
\hline & & The ability to read various kinds of tool of measurement & 1 & $1 \mathrm{e}$ & & \\
\hline & & Assiduousness in using measured data & 1 & $1 \mathrm{f}$ & & \\
\hline \multirow{4}{*}{2} & \multirow{4}{*}{$\begin{array}{l}\text { Equipment } \\
\text { Assembling } \\
\text { (2) }\end{array}$} & Assembling equipment by the book & 1 & $2 \mathrm{a}$ & & \\
\hline & & Collaboration among group members & 1 & $2 b$ & & \\
\hline & & Discussion within group & 1 & $2 c$ & & \\
\hline & & Accuracy of time & 1 & $2 \mathrm{~d}$ & & \\
\hline \multirow{4}{*}{3} & \multirow{4}{*}{$\begin{array}{l}\text { Data } \\
\text { Collection } \\
\text { (3) }\end{array}$} & Recording data of experiment & 1 & $3 a$ & & \\
\hline & & Calculating data of experiment & 1 & $3 b$ & & \\
\hline & & Logical data & 1 & $3 c$ & & \\
\hline & & Drawing conclusion from collected data & 1 & $3 \mathrm{~d}$ & & \\
\hline \multirow{4}{*}{4} & \multirow{4}{*}{$\begin{array}{l}\text { Final } \\
\text { Activity (4) }\end{array}$} & The ability to explain the meaning of collected data & 1 & $4 a$ & & \\
\hline & & Discipline in cleaning up the tools and materials & 1 & $4 \mathrm{~b}$ & & \\
\hline & & Discipline in putting away the tools and materials & 1 & $4 \mathrm{c}$ & & \\
\hline & & Punctuality of submission & 1 & $5 \mathrm{a}$ & & \\
\hline \multirow[b]{2}{*}{5} & \multirow{2}{*}{$\begin{array}{l}\text { Reporting } \\
(5)\end{array}$} & Completeness of content & 1 & $5 b$ & & \\
\hline & & $\begin{array}{l}\text { Logical content (the promptness of theoretical concept and } \\
\text { practical product) }\end{array}$ & 1 & $5 c$ & & \\
\hline
\end{tabular}

\section{Blue Print of Observation Sheet of Student Performance}

The score on the observation sheet of student performance comprises score 3, 2 and 1 . Score 3 is given if the descriptor is observable with good product, score 2 if the descriptor is observable, but with bad product, while score 1 is for the unobservable decriptor. The observed items include such aspects as 1) Preparation, 2) Equipment Assembling, 3) Data Collection, 4) Final Activity, and 5) Reporting.
For the sake of objectivity of scoring, the use of a rigid and comprehensive scoring norm is a must. As such, whoever takes the score of similar performance will not be too much different.

\section{Procedure of Action Research}

The research design is presented in the scheme of Figure 2. 
Table 3. Observation Guidelines

\begin{tabular}{|c|c|c|c|c|c|}
\hline No & Aspect & Indicator & $\begin{array}{l}\text { Descriptor observable with } \\
\text { good product } \\
(3)\end{array}$ & $\begin{array}{l}\text { Scoring Descriptor } \\
\text { Descriptor } \\
\text { observable with bad } \\
\text { product } \\
(2)\end{array}$ & $\begin{array}{c}\text { Descriptor unobservable } \\
\text { (1) }\end{array}$ \\
\hline \multirow[t]{6}{*}{1} & \multirow[t]{6}{*}{ Preparation } & $\begin{array}{l}\text { Recognizing the } \\
\text { tools and materials } \\
\text { used }\end{array}$ & $\begin{array}{l}\text { Students can recognize well the } \\
\text { tools and materials used }\end{array}$ & $\begin{array}{l}\text { Students can recognize well the } \\
\text { tools and materials used after } \\
\text { explained by the lecturer }\end{array}$ & $\begin{array}{l}\text { Students cannot recognize } \\
\text { well the tools and materials } \\
\text { used }\end{array}$ \\
\hline & & $\begin{array}{l}\text { The tools and } \\
\text { materials matched } \\
\text { with the objective of } \\
\text { experiment }\end{array}$ & $\begin{array}{l}\text { By referring to the manual of } \\
\text { practicum, students can choose } \\
\text { the tools and materials matched } \\
\text { with the objective of experiment } \\
\text { by their own }\end{array}$ & $\begin{array}{l}\text { Students can choose the tools } \\
\text { and materials matched with the } \\
\text { objective of experiment by } \\
\text { asking the lecturer }\end{array}$ & $\begin{array}{l}\text { Students cannot choose the } \\
\text { tools and materials matched } \\
\text { with the objective of } \\
\text { experiment }\end{array}$ \\
\hline & & $\begin{array}{l}\text { The accuracy of tool } \\
\text { selection }\end{array}$ & $\begin{array}{l}\text { Of the varied available tools, } \\
\text { students can choose the right } \\
\text { one accurately }\end{array}$ & $\begin{array}{l}\text { Of the varied available tools, } \\
\text { students can choose the right } \\
\text { one accurately with the help of } \\
\text { others }\end{array}$ & $\begin{array}{l}\text { Of the varied available tools, } \\
\text { students cannot choose the } \\
\text { right one accurately }\end{array}$ \\
\hline & & $\begin{array}{l}\text { The accuracy of tool } \\
\text { usage }\end{array}$ & $\begin{array}{l}\text { Students can use the tool } \\
\text { accurately without help from } \\
\text { others }\end{array}$ & $\begin{array}{l}\text { Students can use the tool } \\
\text { accurately with help from others }\end{array}$ & $\begin{array}{l}\text { Students cannot use the tool } \\
\text { accurately }\end{array}$ \\
\hline & & $\begin{array}{l}\text { The ability to read } \\
\text { various kinds of tool } \\
\text { of measurement }\end{array}$ & $\begin{array}{l}\text { Students can clearly show the } \\
\text { readability of the tool of } \\
\text { measurement used }\end{array}$ & $\begin{array}{l}\text { Students can clearly show the } \\
\text { readability of the tool of } \\
\text { measurement used with the help } \\
\text { of friend in group }\end{array}$ & $\begin{array}{l}\text { Students cannot show the } \\
\text { readability of the tool of } \\
\text { measurement used }\end{array}$ \\
\hline & & $\begin{array}{l}\text { Assiduousness in } \\
\text { using measured data }\end{array}$ & $\begin{array}{l}\text { Students can analyze well the } \\
\text { data of experiment }\end{array}$ & $\begin{array}{l}\text { Students can analyze well the } \\
\text { data of experiment with the help } \\
\text { of friend in group }\end{array}$ & $\begin{array}{l}\text { Students cannot analyze well } \\
\text { the data of experiment }\end{array}$ \\
\hline \multirow[t]{4}{*}{2} & \multirow[t]{4}{*}{$\begin{array}{l}\text { Equipment } \\
\text { Assembling }\end{array}$} & $\begin{array}{l}\text { Assembling } \\
\text { equipment by the } \\
\text { book }\end{array}$ & $\begin{array}{l}\text { By referring to the manual of } \\
\text { practicum, students can assemble } \\
\text { the equipment by themselves }\end{array}$ & $\begin{array}{l}\text { By referring to the manual of } \\
\text { practicum, students can assemble } \\
\text { the equipment with the help of } \\
\text { others }\end{array}$ & $\begin{array}{l}\text { By referring to the manual of } \\
\text { practicum, students cannot } \\
\text { assemble the equipment }\end{array}$ \\
\hline & & $\begin{array}{l}\text { Collaboration } \\
\text { among group } \\
\text { members }\end{array}$ & $\begin{array}{l}\text { There is good collaboration } \\
\text { among group members to } \\
\text { assemble the equipment }\end{array}$ & $\begin{array}{l}\text { There is bad collaboration } \\
\text { among group members to } \\
\text { assemble the equipment }\end{array}$ & $\begin{array}{l}\text { There is no collaboration } \\
\text { among group members to } \\
\text { assemble the equipment }\end{array}$ \\
\hline & & $\begin{array}{l}\text { Discussion within } \\
\text { group }\end{array}$ & $\begin{array}{l}\text { Discussion within group } \\
\text { happens }\end{array}$ & $\begin{array}{l}\text { Discussion within group } \\
\text { happens but not running well }\end{array}$ & $\begin{array}{l}\text { Discussion within group does } \\
\text { not happen }\end{array}$ \\
\hline & & Accuracy of time & $\begin{array}{l}\text { Accuracy of time to assemble } \\
\text { equipment with good result }\end{array}$ & $\begin{array}{l}\text { Accuracy of time to assemble } \\
\text { equipment with bad result }\end{array}$ & $\begin{array}{l}\text { Inaccuracy of time to } \\
\text { assemble equipment }\end{array}$ \\
\hline \multirow[t]{4}{*}{3} & \multirow[t]{4}{*}{$\begin{array}{l}\text { Data } \\
\text { Collection }\end{array}$} & $\begin{array}{l}\text { Recording data of } \\
\text { experiment }\end{array}$ & $\begin{array}{l}\text { Recording thoroughly data of } \\
\text { experiment }\end{array}$ & $\begin{array}{l}\text { Recording data of experiment, } \\
\text { but not thoroughly }\end{array}$ & $\begin{array}{l}\text { Not recording data of } \\
\text { experiment }\end{array}$ \\
\hline & & $\begin{array}{l}\text { Calculating data of } \\
\text { experiment }\end{array}$ & $\begin{array}{l}\text { Calculating accurately data of } \\
\text { experiment }\end{array}$ & $\begin{array}{l}\text { Calculating data of experiment, } \\
\text { but not accurately }\end{array}$ & $\begin{array}{l}\text { Not calculating data of } \\
\text { experiment }\end{array}$ \\
\hline & & Logical data & Logical data acquired & $\begin{array}{l}\text { Data acquired need further } \\
\text { analysis }\end{array}$ & Illogical data acquired \\
\hline & & $\begin{array}{l}\text { Drawing conclusion } \\
\text { from collected data }\end{array}$ & $\begin{array}{l}\text { Data collected from experiment } \\
\text { are well-interpreted and } \\
\text { concluded }\end{array}$ & $\begin{array}{l}\text { Data collected from experiment } \\
\text { are well interpreted, but not } \\
\text { well-concluded }\end{array}$ & $\begin{array}{l}\text { Data collected from } \\
\text { experiment are not well- } \\
\text { interpreted and concluded }\end{array}$ \\
\hline \multirow[t]{3}{*}{4} & \multirow[t]{3}{*}{ Final Activity } & $\begin{array}{l}\text { The ability to } \\
\text { explain the meaning } \\
\text { of collected data }\end{array}$ & $\begin{array}{l}\text { Able to explain the meaning of } \\
\text { the collected data }\end{array}$ & $\begin{array}{l}\text { With help from others, able to } \\
\text { explain the meaning of the } \\
\text { collected data }\end{array}$ & $\begin{array}{l}\text { Unable to explain the } \\
\text { meaning of the collected data }\end{array}$ \\
\hline & & $\begin{array}{l}\text { Discipline in } \\
\text { cleaning up the } \\
\text { tools and materials }\end{array}$ & $\begin{array}{l}\text { Showing discipline in cleaning } \\
\text { up the tools and materials }\end{array}$ & $\begin{array}{l}\text { Lack of discipline in cleaning up } \\
\text { the tools and materials }\end{array}$ & $\begin{array}{l}\text { Showing indiscipline in } \\
\text { cleaning up the tools and } \\
\text { materials }\end{array}$ \\
\hline & & $\begin{array}{l}\text { Discipline in } \\
\text { putting away the } \\
\text { tools and materials }\end{array}$ & $\begin{array}{l}\text { Showing discipline in putting } \\
\text { away the tools and materials }\end{array}$ & $\begin{array}{l}\text { Lack of discipline in putting } \\
\text { away the tools and materials }\end{array}$ & $\begin{array}{l}\text { Showing indiscipline in } \\
\text { putting away the tools and } \\
\text { materials }\end{array}$ \\
\hline \multirow[t]{3}{*}{5} & \multirow[t]{3}{*}{ Reporting } & $\begin{array}{l}\text { Punctuality of } \\
\text { submission }\end{array}$ & $\begin{array}{l}\text { Punctual in submitting the } \\
\text { report }\end{array}$ & $\begin{array}{l}\text { Not punctual in submitting the } \\
\text { report }\end{array}$ & Not submitting the report \\
\hline & & $\begin{array}{l}\text { Completeness of } \\
\text { content }\end{array}$ & $\begin{array}{l}\text { Report is totally complete } \\
\text { covering title, abstract, } \\
\text { introduction, theoretical } \\
\text { framework, procedure of } \\
\text { experiment, analysis/discussion, } \\
\text { conclusion and references }\end{array}$ & $\begin{array}{l}\text { Report content is partly } \\
\text { complete covering title, abstract, } \\
\text { introduction, theoretical } \\
\text { framework, procedure of } \\
\text { experiment, analysis/discussion, } \\
\text { conclusion and references }\end{array}$ & $\begin{array}{l}\text { Report content is incomplete } \\
\text { to cover title, abstract, } \\
\text { introduction, theoretical } \\
\text { framework, procedure of } \\
\text { experiment, } \\
\text { analysis/discussion, } \\
\text { conclusion and references }\end{array}$ \\
\hline & & $\begin{array}{l}\text { Logical content (the } \\
\text { promptness of } \\
\text { theoretical concept } \\
\text { and practical } \\
\text { product) }\end{array}$ & $\begin{array}{l}\text { Content of report is logical (the } \\
\text { promptness of theoretical } \\
\text { concept and practical product) }\end{array}$ & $\begin{array}{l}\text { Content of report is logical, but } \\
\text { some data are not well- } \\
\text { interpreted }\end{array}$ & $\begin{array}{l}\text { Content of report is illogical } \\
\text { (there in no promptness of } \\
\text { theoretical concept and } \\
\text { practical product) }\end{array}$ \\
\hline
\end{tabular}




\section{Model of Action}

Model of action to be applied is referring to model of Elliot.

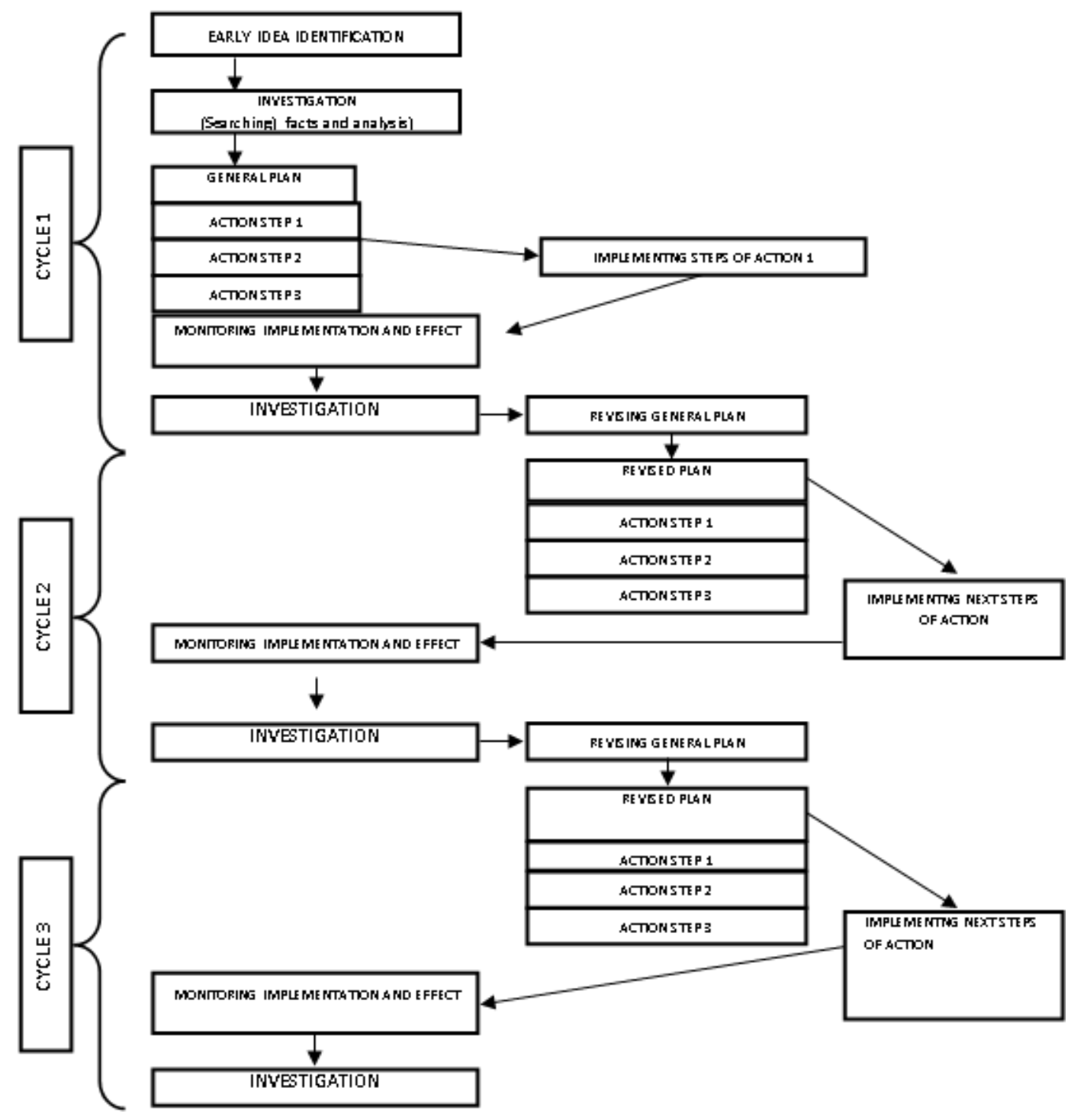

Figure 3. Model of Elliot's Action Research

Source: David Hopkins, A Teacher's Guide to Classroom Research, ed.4. New York:

McGraw Hill-Open University Press. 2008, p.93

\section{Findings and Discussion}

\section{Result of Performance Per Cycle}

Based on the observation checklist for three experimentations in cycle $\mathrm{I}$, it can be seen the number of students with the category of "poor", "good", and "very good". The following table shows the percentage of each category.
Table 4. Category of PA Result in Cycle I

\begin{tabular}{cccc}
\hline Range & Category & Number & Percentage \\
\hline $60-99$ & Poor & 18 & $22.50 \%$ \\
$100-139$ & Good & 42 & $52.50 \%$ \\
$140-179$ & Very Good & 20 & $25.00 \%$ \\
\hline
\end{tabular}

It is displayed in the table 4 above that as many as $22.50 \%$ or 18 students showed poor 
performance during the practicum activity, $52.50 \%$ or 42 students did good performance, while $25.00 \%$ or 20 students demonstrated very good performance. The percentage of the category indicated that the student performance in the practicum activity was normally distributed. Then, to get the improvement of student performance in the practicum activity, the second cycle was carried out.

In the second cycle, just like the first one three experimentations were done to investigate student performance. The categories of student performance were the same as the previous ones: "poor", "good", and "very good". The result of the second cycle can be seen in the following table.

Table 5. Category of PA Result in Cycle II

\begin{tabular}{cccc}
\hline Range & Category & Number & Percentage \\
\hline $60-99$ & Poor & 12 & $15.00 \%$ \\
$100-139$ & Good & 37 & $46.25 \%$ \\
$140-179$ & Very Good & 31 & $38.75 \%$ \\
\hline
\end{tabular}

It is informed in the table above that there were as many as $15.00 \%$ or 12 students showed poor performance, $46.25 \%$ or 37 students demonstrated good performance, while $38.75 \%$ or 31 students did very good performance in the practicum activity of the second cycle.

It points out that there was an increase in each category. For the category of poor performance, the improvement reached $7.5 \%$; for good performance was $6.25 \%$; and for very good performance amounted $13.75 \%$. Despite the fact that there was improvement of student performance in carrying out the practicum activity as indicated in the calculation, the figure of improvement as a whole had not reached $85 \%$ of the total number of students. Therefore, this action research proceeded to the third cycle.

In the third cycle, the intervention of the practicum activity was different from the previous cycles. In this cycle, there were four experimentations i.e. the $7^{\text {th }}$ until the $10^{\text {th }}$ experimentation about refraction, induction I, electromagnetic induction II, and electromagnetic wave respectively. The score range was automatically different too, the lowest score 80 and the highest score 240 . The score range for the three categories was as follows: range $80-133$ for poor performance, range 134 - 187 for good performance, and range 188 241 for very good one. The result of observation was displayed in the table below.

Table 6. Category of PA Result in Cycle III

\begin{tabular}{cccc}
\hline Range & Category & Number & Percentage \\
$80-133$ & Not Good & 7 & $8.75 \%$ \\
$134-187$ & Good & 26 & $32.50 \%$ \\
$188-241$ & Very Good & 47 & $58.75 \%$ \\
\hline
\end{tabular}

It was illustrated in the table above that there were as many as $8.75 \%$ or 7 students showed poor performance, $32.50 \%$ or 26 students did good performance, while $58.75 \%$ or 47 students demonstrated very good performance in carrying the practicum activity. Again, improvement of student performance occurred in this cycle for each category.

\section{Result of Performance between Cycle}

There was improvement of performance from cycle I to cycle II as well as from cycle II to cycle III. The average score of cycle I was 42.508 and cycle II 45.088 indicating that there was improvement of the average score. Then, the average score of cycle II was 45.088 and cycle III 47.816, again, indicating the improvement of the average score. The following graph displays the improvement more clearly. 


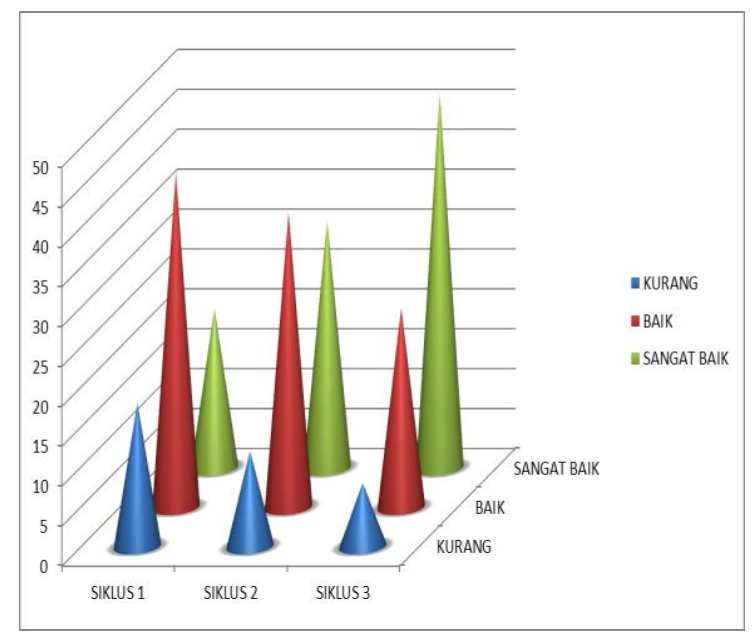

Graph 1. The Improvement of Performance in Cycles 1, 2 and 3

The graph illustrates the score improvement of student performance in carrying out practicum activity in the three cycles e.g. for the category of "very good" in cycle I was $25 \%$, in cycle II $38.75 \%$, and in cycle III $58.75 \%$. Meanwhile, the number of students who belonged to the category of "not good" was decreasing in each cycle which meant that there was an increase in quality, in cycle I $22.50 \%$, in cycle II $15.00 \%$, and in cycle III $8.75 \%$. Finally there were only $8.75 \%$ students who were categorized "not good" and 91.25\% students demonstrated "very good" performance. Thus, the action was stopped up to the third cycle.

\section{Conclusions}

There was improvement of student performance as described below.

1. In cycle I, $22.50 \%$ of all students were categorized "not good", 52.50\% "good" and $25.00 \%$ "very good" in performing the practicum activity.

2. In cycle II, $15.00 \%$ students fell under the category of "not good", 46.25\% "good", and $38.75 \%$ "very good" in performing the practicum activity.
3. In cycle III, there were as many as $8.75 \%$ students considered "not good", $33.75 \%$ "good", and $57.50 \%$ "very good" in performing the practicum activity.

The obstacles found in the implementation of PA in the practicum activity included: (a). Unfamiliarity with the implementation of PA, (b). Limited number of lecturers and their time constraint, (c). Lack of knowledge and understanding of the basic concept of PA, and (d). Apathy of new kind of assessment system.

\section{References}

Baedhowi. "Kebijakan Assessment Dalam Kurikulum Tingkat Satuan Pendidikan (KTSP).” www.depdiknas.go.id/publikasi/balitbang/j urnal pendidikan dan kebudayaan/Volume 63 05, accessed on 12 June 2011.

Burke, Kay. (2009). How to Assess Authentic Learning. Fifth Edition. New Delhi. Mathura Road.

Campbell, Bruce. Linda Campbell dan Dee Dickinson. (2006). Teaching and Learning Through Multiple Intellegence. Rucson: Zephyr Press.

Cresswel, John. W. (2003). Research Design: Qualitatif, Quantitatif, And Mix Method Approach. $2^{\text {nd }}$ Edition. California : Sage Publications, Inc.

Danilelson, Charlote, S, "A Collection of Performance Task and Rubriks; Middle School Mathematics". http//www.assesment.com/Danilso (accessed on 10 March 2011).

Gardner, Howard. (2003). Multiple Intellegences. (Terjemahan) Alexander Sindoro, Batam Centre.

Hopkins, David. (2002). A Teacher's Guide to Classroom Research, third edition. Buckingham-Open University Press. 
Muchtar, Hartati. "Penerapan Penilaian Autentik dalam upaya Peningkatan Mutu Pendidikan. Jurnal Pendidikan Penabur No.14/Tahun ke-9/Juni 2010. http://www.bkppenabur.or.id/files/Hal.\% 2068-

$\% 20$ penerapan $\% 20$ penilaian $\% 20$ autentik. pdf (accessed on 20 September 2010).

Reynolds, Cecil R. (2009). Ronald B. Livingston, and Victor Willson, Measurement and Assessment in Education. Second Edition. Upper Saddle River, New Jersey Columbus, Ohio.
Stiggins, Richard J. (2007). Conquering the Formatif Assessment Frontier; Formatif Classroom Assessment, editing by: James H.McMillan. New York: Teachers College Press.

Zainul, Asnawi. (2001). Alternative Assessment Applied Approach mengajar di perguruan Tinggi buku 2.09. Pusat antar universitas untuk peningkatan dan pengembangan aktivitas instruksional. Dirjen Dikti Depdiknas. Jakarta. 